\title{
Firms Political Connections and Winning Government Contracts
}

\author{
Saidatou Dicko ${ }^{1}$ \\ ${ }^{1}$ Accounting Departement, School of Management, Université du Québec à Montréal, Montreal, Canada \\ Correspondence: Saidatou Dicko, Accounting Departement, School of Management, Université du Québec à \\ Montréal, Montreal, Quebec., H2X 3X2, Canada. Tel: 1-514-987-3000 ext. $3848 . \quad$ E-mail: \\ saidatou.hamidou_dicko@uqam.ca
}

Received: November 26, 2015

Accepted: December 8, 2015 Online Published: January 25, 2016

doi:10.5539/ijef.v8n2p19

URL: http://dx.doi.org/10.5539/ijef.v8n2p19

\begin{abstract}
This study investigates the impact of political connections on the awarding of government contracts to Canadian companies. Two-stage least squares (2SLS) analyses were performed on a sample of S\&P/TSX companies from 2010 to 2014 inclusively. The results show that political connections are positively and significantly associated with the winning of government contracts. Politically connected firms obtain more government contracts and higher contract values than non-connected firms. Political connections thus appear to be directly associated with securing government contracts in the Canadian context. Firms can view political connections as a non-market, long-term strategy to help them gain competitive advantages and improve their performance. Accordingly, they tend to appoint directors and managers taking these connections and the advantages that can be gained into account. However, they must seriously consider the cost-benefit ratio of this strategy. For example, the costs incurred could be ethical in nature and firms could find themselves in a position of conflict of interest that could lead to extensive negative media exposure. These results alert regulatory and governmental organizations to the need for them to remain vigilant and to strengthen corporate governance regulations to prevent the excesses and abuses that could arise from firms' political actions. Our study is the first to demonstrate a direct relationship between corporate political connections and government contracts in the Canadian context. The results confirm the growing interdependence between politics and business, particularly the increase in the number of corporate actions intended to influence government decisions.
\end{abstract}

Keywords: Canadian, firms, government contracts, performance, political connections, S\&P/TSX

\section{Introduction}

Firms need key resources to maintain their profitability and growth. According to resource dependence theory, they have to connect to the external environment to access the resources they require, which can be accomplished through a variety of means. Political connections are one of the most important of these means.

The past decade has seen various studies on the role and impact of corporate political connections in different countries (Goldman, Rocholl, \& So, 2009; Goldman, Rocholl, \& So, 2013; Houston, Jiang, Lin, \& Yuema, 2014; Yan, Wilson, \& Wu, 2014). These studies focus mainly on firms' financial performance. Research conducted in Canada has shown that political connections positively influence the financial performance of firms (Dicko \& Khemakhem, 2015), although little is known about how political connections help them gain access to external resources.

According to Dicko (2011), firms sometimes use directors' social connections to access different types of resources, which could be financial (bank financing), commercial (new contracts), informational, or expertise-related. The current study will examine a different type of asset, i.e. political connections, to determine whether they help Canadian firms obtain government contracts.

Why study government contracts in particular? Because government is the construction industry's most important client in Canada and companies go to great lengths to win government contracts. It is thus important to investigate the relationship between firms' political connections and their ability to win specific contracts. It is also of interest for society and government to understand how companies can influence decision-making in the government procurement process.

Numerous studies have been carried out in the United States to identify and analyse the determinants of firms' political activities, which include contributions to political action committees, lobbying, soft money 
contributions, and advocacy advertising. Defined as "any deliberate firm action intended to influence governmental policy or process" (Getz, 1997, p. 32), firms' political activities or actions have been theoretically recognized as non-market strategies that can help shape their relationships with government, influence government policies, and achieve competitive advantages (Hadani, 2007). Despite the extent of studies conducted, little is known about the empirical use of political connections by firms. It is therefore extremely important to investigate the direct and empirical link between firms' political activities and the benefits they can provide.

For S\&P/TSX companies, our findings show that political connections positively and significantly influence the ability of non-financial firms to win government contracts. We were thus able to confirm our hypotheses. Our study is therefore the first to make an empirical link between a firm's having political connections and using them effectively. These results constitute an appeal to regulatory and government organizations since they confirm the need for them to review their regulations and processes.

\section{Business Resource Dependence and Social Connections}

Firms are primarily social institutions that have a social contract with society as a whole. This contract allows them to use collective resources within the limits of the law to create and effectively disseminate wealth, supposedly in proportion to participation in the production process or the value of each production factor on a market. However, with the expansion of globalization and competition, each company now constantly faces significant challenges that can affect its growth and sustainability. Firms continually need to renew themselves, and to do so, they have to rely on their environmental resources. Yet these resources can become scarce when new players enter the market. Therefore, in order to survive and prosper, companies need to apply creative strategies to access their environmental resources. This premise is supported by the resource dependence theory, which states that the survival and even the success of an organization depend on its ability to manage its relationship with the environment (Pfeffer \& Salancik, 1978).

Thus, according to Pfeffer:

"Organizations require personnel, money, social legitimacy, customers, and a variety of technological and material inputs in order to continue to function. [...] There are numerous resources which potentially can be the focus around which power is organized. These include money, prestige, legitimacy, rewards and sanctions, and expertise, or the ability to deal with uncertainty. (Pfeffer, 1981, p. 101)".

There are several ways companies can obtain the external resources they need. According to some economic sociology theories (e.g. social capital theory (Bourdieu, 2000) and resource dependence theory), social connection networks, such as board members' affiliations, can be an excellent way for firms to access these resources. Lemieux (2000) maintains that social connection networks can be used to recognise links and affiliations, circulate information, provide assistance, take action in conflict or cooperation situations, link economic agents (business connections), and monitor public policies.

Political connections appear to be the most sought-after, and probably the most effective, social connections for companies. Certainly, current realities reflect increased interaction between politics and business. More specifically, since politicians' primary role as society's representatives is to regulate the sharing of collective resources, it is advantageous for firms to control political decisions in order to obtain easier access to these resources. To an increasing extent, politicians' financial dependence on businesses is making it easier for companies to exercise control. Breton and Pesqueux (2006) argue that firms influence society because they affect its representatives (politicians), particularly through the financing they provide. Companies therefore have control over regulations and public policy. Furthermore, shareholders, managers and politicians often belong to the same social class, the same clubs, and the same associations.

\section{Business and Government Officers belong to the Same Elite}

In our system, corporations have more power than politicians because politicians depend heavily on businesses for financing. Given the number of actors who switch from business to politics and vice versa, connections between politics and corporations are unavoidable.

The politicians are financed by enterprises or their owners. Consequently, they are attached by this financing when they reach a position of power, although relative. However, they do not have to be bought necessarily. Politicians are from the same social class, schools, social clubs than entrepreneurs and managers. Therefore, they believe in the same ideas and participate in the same movements or ideologies. Politicians often come from the entrepreneurial community or are professionals, lawyers, for instance, who had close relationships with the business community before their election. (Breton \& Pesqueux, 2006, p. 19) 
In this respect, former politicians contribute an extremely important type of social capital (Bourdieu, 1986) to companies when they decide to become directors or executive members, their political connections. This social capital can give firms access to numerous advantages at different levels of government, especially in relation to contracts and financing.

For Bourdieu (1980), social capital represents the social effects of a group (family, former elite, school, fraternity, nobility, etc.) capacity to mobilise capital (cultural and economic). In this sense, capital attracts capital: its acquisition and sharing can be achieved in a social space where other members of society also have cultural, economic and social capital.

In society, people who possess and have the ability to mobilise these three kinds of capital are considered as an elite group and as belonging to the same environment. They may be from a capitalist, economic and financial elite (corporate managers/owners, bankers), a political elite (politicians), or other (professionals such as architects, engineers, and so on) (Zald, 1969; Galaskiewicz, 1985; Hill, 1995; Mizruchi, 1996). The members of these elite groups attended the same universities, belong to the same associations and clubs and have the same affiliations. Whether they are in politics or business, they meet and communicate with each other at various activities. Firms appoint people from government or politics; business people move into politics and hold government functions.

\section{From Government to Business and Vice Versa: The Canadian Context}

The Parliament of Canada Act contains no provisions about switching from politics to business or vice versa. It simply stipulates that a person cannot cumulate business and political functions; no restrictions are placed on moving from business to politics or in the opposite direction.

In the province of Quebec, a person can cross over from business to politics without restriction. However, the situation differs when it comes to moving from politics to business. Under the Quebec Code of Ethics and Conduct of the Members of the National Assembly, no Cabinet Minister may, for example, hold the post of director or officer of a legal person, partnership or association. Moreover, Cabinet Ministers may not, in the two years after they leave office, accept any appointment to a board of directors or as a member of any body, agency, enterprise or other entity that is not a State entity.

Both at the federal and the provincial levels, a Member of Parliament, Member of the Provincial Parliament, Member of the National Assembly or Member of the Legislative Assembly may be a shareholder of a company. As well, in these jurisdictions, switching from politics to business and vice versa remains relatively easy.

\section{Research on Firms' Political Connections and Hypotheses}

As mentioned above, the numerous studies that have been carried out primarily examined the US context. However, while most of these focus on the relationship between political connections and firms' financial performance, some merely describe the nature and the extent of firms' political activities (Shaffer \& Hillman, 2000; Hillman, 2003).

\subsection{Political Connections and Firms' Financial Performance}

The literature by and large demonstrates that firms' political connections influence their financial performance. Claessens, Feijen, and Laeven (2008) indicate that in the period surrounding the 1998 and 2002 elections, Brazilian firms that contributed to federally elected deputies posted higher stock returns than other firms.

Based on a sample of S\&P500 companies, Goldman, Rocholl, and So (2009) showed an abnormal positive stock return following the appointment of a board member with political connections. They also concluded that subsequent to the US Republican presidential victory in 2000, companies connected to the Republican Party increased in value (measured by stock returns), while those connected to the Democratic Party saw their value decrease.

Using a large sample of non-financial firms from 77 countries, Boubakri, Mansi, and Saffar (2013) investigated the impact of political institutions on corporate risk taking and found that, from 1988 to 2008, solid political institutions were positively associated with corporate risk taking. In a subsample of 45 countries, they also found that politically connected firms engaged in greater risk. They thus suggest that close ties to government lead to less conservative investment decisions and possibly to higher performance.

Brockman, Rui, and Zou (2013) studied the link between a firm's political connections and its merger and acquisition performance. Using a sample of mergers and acquisitions made by politically connected acquirers and their matching non-connected peers across 22 countries, they found that political connections played an economically significant role in post-merger performance. The nature of this effect depended on the institutional 
setting. In countries with strong legal systems or low levels of corruption, politically connected bidders underperformed unconnected bidders by roughly $15 \%$ in terms of abnormal stock returns over a three-year period. In contrast, politically connected bidders outperformed unconnected bidders by more than $20 \%$ in countries where the legal system is weak or corruption levels high. The authors found more evidence of differential post-merger performance for domestic mergers than for cross-border mergers.

In the Canadian context, Dicko and Khemakhem (2015) showed that politically connected S\&P/TSX firms performed better financially (measured by return on assets and return on equity) than non-politically connected firms.

\subsection{Political Connections and Access to Financial Resources}

Dinc (2005) investigated the influence of politics on government-owned banks in 43 countries (excluding the United States), finding that, relative to private banks, these banks increased their lending in election years. This effect was robust when controlling for country-specific macroeconomic and institutional factors, as well as for bank-specific factors. The increase in lending was equivalent to about $11 \%$ of a government-owned bank's total loan portfolio, or about $0.5 \%$ of the country's median GDP per election per government-owned bank.

Working with a sample of Thai firms before the 1997 Asian financial crisis, Charumilind, Kali, and Wiwattanakantang (2006) examined whether business connections predicted preferential access to long-term bank credit. They found that firms with connections to banks and politicians had greater access to long-term debt than firms without such ties. Connected firms needed less collateral, obtained more long-term loans, and appeared to use fewer short-term loans than those without connections.

Faccio, Masulis, and McConnell (2006) analysed the likelihood of a government bailout of 450 politically connected firms in 35 countries between 1997 and 2002. They found that politically connected firms were significantly more likely to be bailed out than similar non-connected firms. In addition, politically connected firms were disproportionately more likely to be bailed out when the International Monetary Fund or the World Bank provided financial assistance to the firms' home government. Furthermore, among the bailed-out firms, those with political connections exhibited significantly poorer financial performance than their non-connected peers at the time of and following the bailout.

Claessens, Feijen, and Laeven (2008) showed that, relative to a control group, Brazilian firms that provided contributions to federally elected deputies substantially increased their bank financing after each election.

Chen, Shen, and Lin (2014) examined whether political connections improved firms' access to financing. Working with a sample of 69,332 individual bank loan contracts for listed firms in Taiwan from 1991 to 2008 , they found that politically connected firms enjoyed preferential treatment for bank loans, benefited more from government-owned banks than from privately owned banks, and received more preferential treatment from government-owned banks during presidential election years.

Based on a hand-collected data set of the political connections of S\&P 500 companies between 2003 and 2008, Houston, Jiang, Lin, and Yuema (2014) found that the cost of bank loans was significantly lower for companies whose board members had political ties.

\subsection{Research Hypotheses}

Although numerous studies have examined corporate political activities in the United States, scant research exists on the relationship between political connections and winning government contracts. One such study by Agrawal and Knoeber (2001) found that firms that had a higher proportion of sales to government also had more politically connected directors on their board. The study was based on a sample of 264 manufacturing firms on the Forbes 800 list in 1987.

Wang (2014) concluded that $22.35 \%$ of the total revenue of politically connected firms was generated by Department of Defence contracts, whereas such contracts accounted for $8.68 \%$ of the total revenue of non-connected firms. This result was based on a sample of 112 public companies out of the top 500 recipients of US Department of Defence contracts in 2008.

In the Canadian context, reports in the media about possible corruption and collusion in the construction industry give the impression that politically connected firms receive more government contracts than non-connected firms. In fact, in November 2011, the Quebec Government created a Commission of Inquiry on the Awarding and Management of Public Contracts in the Construction Industry (Note 1). The testimonies heard by this commission showed that the construction industry operates mainly through political connections: politicians receive money for themselves or their party and in return help companies secure government contracts. 
We thus put forward the following main research hypothesis:

H1: There is a positive relationship between political connections and winning government contracts in the Canadian context.

This hypothesis leads to two sub-hypotheses:

H1a: Politically connected firms win more government contracts than non-politically connected firms.

HIb: Politically connected firms win higher-value government contracts than non-politically connected firms.

\section{Sample and Data}

This study examined approximately 250 S\&P/TSX companies. After eliminating financial and insurance companies, our final list contains some 220 firms. The list of these companies was downloaded from the Compustat database for the period from 2010to 2014 inclusively. Financial data were also retrieved from the same source, while data on firms' political connections were hand collected from the BoardEx database. Information about government contracts derives from the Government of Canada's Public Works and Government Services website, buyandsell.gc.ca/procurement-data.

\section{Analysis Model}

We used the following model to achieve our research objective:

$$
G C=a+b 1 P C+b 2 F S+b 3 F P+b 4 D e b t+b 5 I+b 6 U . S .+\varepsilon
$$

Where:

$$
\begin{aligned}
& \text { GC = government contracts } \\
& a=\text { constant } \\
& \text { PC = political connections } \\
& \text { FS = firm size } \\
& \text { FP = financial performance } \\
& \text { Debt = indebtedness } \\
& \text { I = industry } \\
& \text { US = US listing } \\
& \varepsilon=\text { error term }
\end{aligned}
$$

In this model, all our variables could be endogenous. For example, some studies have shown that political connections have an impact on firm financial performance. To deal with this endogeneity problem, we have decided to perform a two-stage least square analyses. Thus, our second model is the following:

$$
F P=a+b 1 P C+b 2 G C+b 3 F S+b 4 D e b t+b 5 I+b 6 U . S .+\varepsilon
$$

\section{Study Variables}

The model contains one dependent variable (government contracts) and one independent variable (political connections). We have also included several control variables that can potentially influence the firms' revenues. In fact, a government contract secured by a firm constitutes part of it revenues. Financial literature recognises certain variables, such as firm size, financial capacities (equity and debt) and past financial performance, as having an influence on a firm's revenue.

\subsection{Dependent Variable: Government Contracts}

In this study, what we consider as government contract is any purchase of goods and services made by the Canadian federal. This purchase can be made on a long or a short terms. This variable is measured in the following two ways: first, a dummy variable (winning government contracts) is used to measure whether the firm received a government contract between 2009 and 2014 ( 1 if the firm had a government contract and 0 otherwise); a second variable (value of contracts) is used to measure the value of the government contracts obtained.

\subsection{Independent Variable: Political Connections}

Even though firms have a number of options for political action (contributions to political action committees, lobbying, soft money contributions, and advocacy advertising (Hadani, 2007), most studies have used the same 
definition of political connections, i.e., a firm is politically connected when at least one of the members of the board of directors, the executive director or the majority shareholder is currently serving or has served in politics as a Minister, departmental Cabinet member or Member of Parliament. The dummy variable, political connections, is assigned the value of 1 if the firm is politically connected and 0 otherwise.

\subsection{Control Variables}

1). Financial performance. Past studies have shown that three measures of financial performance could be influenced by political connections: return on assets (ROA), return on equity (ROE) and market-to-book value (MTB). In this study, these three variables are used to represent financial performance. ROA is the result of earnings before interest and tax (EBIT) divided by total assets. ROE is EBIT divided by shareholders' equity.

2). Firm size. Since the most common measure of firm size is the natural logarithm of the firm's total revenue, we used this value.

3). Industry. This factor is measured by a dummy variable based on the North American Industry Classification System: 1 for Agriculture, forestry, fishing and hunting; 2 for Mining, quarrying, and oil and gas extraction; 3 for Utilities; 4 for Construction; 5 for Manufacturing; 6 for Wholesale trade; 7 for Retail trade; 8 for Transportation and warehousing; 9 for Information and cultural industries; 10 for Finance and insurance; 11 for Real estate and rental and leasing; 12 for Professional, scientific and technical services; 13 for Management of companies and enterprises; 14 for Administrative and support, waste management and remediation services; 15 for Educational services; 16 for Health care and social assistance; 17 for Arts, entertainment and recreation; 18 for Accommodation and food services; and 19 for Other services.

4). Indebtedness. Capital structure is an extremely important factor that can influence corporate operations. In this study, this variable is measured by the ratio of long-term debt to shareholders' equity.

5). US listing. Owing to Canada's close business ties with the United States, many Canadian companies are also listed on US financial markets. Since certain regulations in the US (e.g. on corporate governance) are more stringent than in Canada, Canadian companies behave differently when listed on US financial markets (Khemakhem \& Dicko, 2013; Dicko \& Khemakhem, 2015). We therefore decided to include this variable in our study, using a dummy variable valued at 1 if the company is listed on US markets and 0 otherwise.

\section{Descriptive Statistics and ANOVA Results}

Table 1 presents information about all the S\&P/TSX firms analysed in this study, including financial and insurance companies, showing that this industry accounts for $11.6 \%$. After eliminating financial and insurance companies, the final list of firms examined is mainly comprised of companies from Mining, quarrying, and oil and gas extraction (85), followed by firms from Manufacturing (37); Real estate and rental (21); Information and cultural industries (16); Utilities (12); Retail trade (12); Transportation and warehousing (11); Wholesale trade (7); Construction (6); Professional, scientific and technical services (6); Administrative and support (3); Arts, entertainment and recreation (2); Accommodation and food services (2); and Healthcare and social assistance industries (1). The list does not include any companies from Agriculture, fishing and hunting. It is important to note that the industry classification of certain companies is not that evident. For instance, some companies that specialise in construction and engineering, such as SNC-Lavalin, are classified in professional, scientific and technical services rather than construction. 
Table 1. Sample statistics by industry

\begin{tabular}{cccccc}
\hline & Industry & $\begin{array}{c}\text { Number of } \\
\text { firms }\end{array}$ & $\begin{array}{c}\text { Frequency over an } \\
\text { average of five years }\end{array}$ & Percentage & $\begin{array}{c}\text { Cumulative } \\
\text { percentage }\end{array}$ \\
\hline 2 & Mining, quarrying, and oil and gas extraction & 85 & 427 & 34.4 & 34.4 \\
3 & Utilities & 12 & 60 & 4.8 & 39.2 \\
4 & Construction & 6 & 29 & 2.3 & 41.5 \\
5 & Manufacturing & 37 & 183 & 14.7 & 56.2 \\
6 & Wholesale trade & 7 & 36 & 2.9 & 59.1 \\
7 & Retail trade & 12 & 59 & 4.7 & 63.9 \\
8 & Transportation and warehousing & 11 & 55 & 4.4 & 68.3 \\
9 & Information and cultural industries & 16 & 78 & 6.3 & 74.6 \\
10 & Finance and insurance & 29 & 144 & 11.6 & 86.2 \\
11 & Real estate and rental and leasing & 21 & 104 & 8.4 & 94.5 \\
12 & Professional, scientific and technical services & 6 & 29 & 2.3 & 96.9 \\
14 & Administrative and support, waste management & 3 & 15 & 1.2 & 98.1 \\
16 & and remediation services & & & & 9.4 \\
17 & Health care and social assistance & 1 & 5 & 0.4 & 98.5 \\
18 & Arts, entertainment and recreation & 2 & 10 & 0.7 & 100.0 \\
\hline
\end{tabular}

Table 2 presents descriptive statistics (number of observations, mean, standard deviation, minimum and maximum) according to political connections, showing that the mean of firm size is higher for politically connected firms than for non-connected firms (7.52 vs 6.63).

Table 2. Descriptive statistics according to political connections

\begin{tabular}{|c|c|c|c|c|c|c|}
\hline & & No. & Mean of the variable & St. deviation & Minimum & Maximum \\
\hline \multirow{3}{*}{ Firm size } & Firm is not politically connected & 540 & 6.635880 & 1.4503672 & -0.9138 & 10.6355 \\
\hline & Firm is politically connected & 529 & 7.520136 & 1.6018933 & 0.8953 & 10.6901 \\
\hline & Total & 1069 & 7.073459 & 1.5893033 & -0.9138 & 10.6901 \\
\hline \multirow{3}{*}{ ROA } & Firm is not politically connected & 560 & 0.058383 & 0.0985232 & -1.0895 & 0.5196 \\
\hline & Firm is politically connected & 535 & 0.066070 & 0.0673285 & -0.4613 & 0.3602 \\
\hline & Total & 1095 & 0.062139 & 0.0847783 & -1.0895 & 0.5196 \\
\hline \multirow{3}{*}{ ROE } & Firm is not politically connected & 560 & 0.132165 & 0.1717760 & -0.8338 & 0.8353 \\
\hline & Firm is politically connected & 535 & 0.182449 & 1.2990083 & -20.2963 & 18.9524 \\
\hline & Total & 1095 & 0.156733 & 0.9161709 & -20.2963 & 18.9524 \\
\hline \multirow{3}{*}{$\begin{array}{l}\text { Market-to-book } \\
\text { value }\end{array}$} & Firm is not politically connected & 560 & 2.183107 & 2.3873649 & -6.5711 & 24.2861 \\
\hline & Firm is politically connected & 535 & 1.978237 & 12.0803299 & -229.0280 & 148.4757 \\
\hline & Total & 1,095 & 2.083011 & 8.6113772 & -229.0280 & 148.4757 \\
\hline \multirow{3}{*}{ Indebtedness } & Firm is not politically connected & 560 & 0.548579 & 0.7030918 & -1.7279 & 7.3859 \\
\hline & Firm is politically connected & 535 & 0.833888 & 11.3932389 & -180.9904 & 181.5952 \\
\hline & Total & 1095 & 0.687977 & 7.9770554 & -180.9904 & 181.5952 \\
\hline \multirow{3}{*}{ US listing } & Firm is not politically connected & 79 & 0.94 & 0.245 & 0 & 1 \\
\hline & Firm is politically connected & 96 & 1.00 & 0.000 & 1 & 1 \\
\hline & Total & 175 & 0.97 & 0.167 & 0 & 1 \\
\hline \multirow{3}{*}{ Industry } & Firm is not politically connected & 563 & 4.63 & 3.550 & 2 & 18 \\
\hline & Firm is politically connected & 536 & 6.24 & 3.890 & 2 & 17 \\
\hline & Total & 1099 & 5.41 & 3.804 & 2 & 18 \\
\hline \multirow{3}{*}{$\begin{array}{c}\text { Winning } \\
\text { government } \\
\text { contracts }\end{array}$} & Firm is not politically connected & 563 & 0.08 & 0.277 & 0 & 1 \\
\hline & Firm is politically connected & 536 & 0.14 & 0.351 & 0 & 1 \\
\hline & Total & 1099 & 0.11 & 0.317 & 0 & 1 \\
\hline \multirow{3}{*}{ Value of contracts } & Firm is not politically connected & 563 & 1796126.45 & 16511554.36 & 0.0000 & $2.4680 \mathrm{E}+8$ \\
\hline & Firm is politically connected & 536 & 6984672.01 & 64758659.63 & 0.0000 & $1.1099 \mathrm{E}+9$ \\
\hline & Total & 1,099 & 4326663.69 & 46793659.01 & 0.0000 & $1.1099 \mathrm{E}+9$ \\
\hline
\end{tabular}


We note the same pattern for ROA (0.066 vs 0.058$)$, ROE ( 0.182 vs 0.132$)$, indebtedness ( 0.833 vs 0.548 ) and value of contracts (6984672 vs 1796126). In other words, the mean value of contracts of politically connected firms is higher than the mean value of contracts of non-connected firms. Politically connected firms are larger than non-connected firms, and have a higher ROA and ROE. However, they are more indebted than their non-connected counterparts.

Conversely, the mean of market-to-book value of non-politically connected firms is higher than that of politically connected firms (2.183. 1.978). In addition, more politically connected firms are listed on US market than non-connected firms (96 vs 79).

Table 3. Descriptive statistics according to political connections and winning government contracts

\begin{tabular}{|c|c|c|c|c|c|}
\hline & & & \multicolumn{2}{|c|}{ Political connections } & \multirow[b]{2}{*}{ Total } \\
\hline & & & $\begin{array}{l}\text { Firm is not politically } \\
\text { connected }\end{array}$ & $\begin{array}{c}\text { Firm is politically } \\
\text { connected }\end{array}$ & \\
\hline \multirow{8}{*}{$\begin{array}{l}\text { Winning } \\
\text { government } \\
\text { contracts }\end{array}$} & \multirow{4}{*}{$\begin{array}{l}\text { Firm has not won } \\
\text { government contracts }\end{array}$} & Number & 516 & 459 & 975 \\
\hline & & $\%$ in Winning government contracts & $52.9 \%$ & $47.1 \%$ & $100.0 \%$ \\
\hline & & $\%$ in Political connections & $91.7 \%$ & $85.6 \%$ & $88.7 \%$ \\
\hline & & $\%$ du total & $47.0 \%$ & $41.8 \%$ & $88.7 \%$ \\
\hline & \multirow{4}{*}{$\begin{array}{l}\text { Firm has won } \\
\text { government contracts }\end{array}$} & Number & 47 & 77 & 124 \\
\hline & & $\%$ in Winning government contracts & $37.9 \%$ & $62.1 \%$ & $100.0 \%$ \\
\hline & & $\%$ in Political connections & $8.3 \%$ & $14.4 \%$ & $11.3 \%$ \\
\hline & & $\%$ du total & $4.3 \%$ & $7.0 \%$ & $11.3 \%$ \\
\hline & \multirow{4}{*}{ Total } & Number & 563 & 536 & 1,099 \\
\hline & & $\%$ in Winning government contracts & $51.2 \%$ & $48.8 \%$ & $100.0 \%$ \\
\hline & & $\%$ in Political connections & $100.0 \%$ & $100.0 \%$ & $100.0 \%$ \\
\hline & & $\%$ du total & $51.2 \%$ & $48.8 \%$ & $100.0 \%$ \\
\hline
\end{tabular}

According to Table 3, 48.8\% of S\&P/TSX companies are politically connected, in comparison to $51.2 \%$ that are not. Also, only $11.3 \%$ of all companies received government contracts, versus $88.7 \%$ that did not. Of those companies that received government contracts, $7 \%$ are politically connected and $4.3 \%$ are not. Some $14.4 \%$ of politically connected firms received government contracts, compared to $85.6 \%$ did not, while $8.3 \%$ of non-politically connected firms received government contracts, in contrast to $91.7 \%$ that did not. Thus, the number of politically connected firms that won government contracts is greater than the number of non-politically connected firms that won such contracts (77 vs 47 ). These results are confirmed by descriptive statistics in Table 2 that show politically connected firms as having a higher mean value of contracts than the mean value of contracts of non-connected firms. These statistics confirm our sub-hypotheses (H1a and H1b).

These descriptive statistics are similar to the findings of Agrawal and Knoeber (2001) and Wang (2014) in the US context. In fact, Agrawal and Knoeber (2001) concluded that politically connected firms had a higher proportion of sales to government than non-connected firms. According to Wang (2014), politically connected firms generated $22.35 \%$ of their total revenue from Department of Defence contracts, in contrast to non-connected firms that generated only $8.68 \%$ of their revenue from such contracts.

Table 4. Results of ANOVA Factor: Political connections

\begin{tabular}{|c|c|c|c|c|c|c|}
\hline & & Sum of square & ddl & Mean square & $\mathrm{F}$ & $\mathrm{P}$ value \\
\hline \multirow{3}{*}{ Firm size } & Inter-groups & 208.943 & 1 & 208.943 & 89.582 & 20.000 \\
\hline & Intragroup & 2488.702 & 1067 & 2.332 & & \\
\hline & Total & 2697.645 & 1068 & & & \\
\hline \multirow{3}{*}{ ROA } & Inter-groups & 0.016 & 1 & 0.016 & 2.252 & 0.134 \\
\hline & Intragroup & 7.847 & 1093 & 0.007 & & \\
\hline & Total & 7.863 & 1094 & & & \\
\hline \multirow{3}{*}{ ROE } & Inter-groups & 0.692 & 1 & 0.692 & 0.824 & 0.364 \\
\hline & Intragroup & 917.578 & 1093 & 0.840 & & \\
\hline & Total & 918.270 & 1094 & & & \\
\hline
\end{tabular}




\begin{tabular}{|c|c|c|c|c|c|c|}
\hline \multirow{3}{*}{ Market-to-book value } & Inter-groups & 11.484 & 1 & 11.484 & 0.155 & 0.694 \\
\hline & Intragroup & 81114.980 & 1093 & 74.213 & & \\
\hline & Total & 81126.464 & 1094 & & & \\
\hline \multirow{3}{*}{ Indebtedness } & Inter-groups & 22.272 & 1 & 22.272 & 0.350 & 0.554 \\
\hline & Intragroup & 69592.681 & 1093 & 63.671 & & \\
\hline & Total & 69614.953 & 1094 & & & \\
\hline \multirow{3}{*}{ US listing } & Inter-groups & 0.174 & 1 & 0.174 & 6.412 & 0.012 \\
\hline & Intragroup & 4.684 & 173 & 0.027 & & \\
\hline & Total & 4.857 & 174 & & & \\
\hline \multirow{3}{*}{ Industry } & Inter-groups & 705.352 & 1 & 705.352 & 50.976 & 0.000 \\
\hline & Intragroup & 15179.272 & 1097 & 13.837 & & \\
\hline & Total & 15884.624 & 1098 & & & \\
\hline \multirow{3}{*}{$\begin{array}{l}\text { Winning government } \\
\text { contracts }\end{array}$} & Inter-groups & 0.994 & 1 & 0.994 & 10.005 & 0.002 \\
\hline & Intragroup & 109.015 & 1097 & 0.099 & & \\
\hline & Total & 110.009 & 1098 & & & \\
\hline \multirow{3}{*}{ Value of contracts } & Inter-groups & 7392081753041844.000 & 1 & 7392081753041844.000 & 3.383 & 0.066 \\
\hline & Intragroup & 2396839801172452400.000 & 1097 & 2184904103165407.800 & & \\
\hline & Total & 2404231882925494300,000 & 1098 & & & \\
\hline
\end{tabular}

Table 4 shows a very significant difference between politically connected and non-connected firms in terms of firm size $(\mathrm{p}$ value $=0.000)$, US listing $(\mathrm{p}$ value $=0.012)$, industry $(\mathrm{p}$ value $=0.000)$ and winning government contracts $(\mathrm{p}$ value $=0.002)$, and a slightly significant difference in the value of these contracts $(\mathrm{p}$ value $=$ 0.066).However, no significant difference was noted between politically connected and non-connected firms in terms of ROA ( $\mathrm{p}$ value $=0.134)$, ROE ( $\mathrm{p}$ value $=0.364)$, market-to-book value $(\mathrm{p}$ value $=0.694)$ or indebtedness $(\mathrm{p}$ value $=0.554)$.

\section{Correlation Analyses and Endogeneity Test Results}

In our model (equation 1), all independent variables could be correlated between themselves or correlated with error term and create problems of collinearity and endogeneity. For example, government contracts could influence financial performance and firm size and indebtedness, as could, according to several studies (Dicko \& Khemakhem, 2015), political connections. For this reason and to determine the extent of collinearity and endogeneity problems, we decided to perform tests using correlation analyses. These analyses identify the variables that are correlated between themselves, particularly independent variables. A correlation coefficient of $50 \%$ or more is generally considered a critical level that could lead to collinearity problems.

Table 5. Results of Pearson correlation analysis

\begin{tabular}{|c|c|c|c|c|c|c|c|c|c|c|c|}
\hline & & 1 & 2 & 3 & 4 & 5 & 6 & 7 & 8 & 9 & 10 \\
\hline 1 & Firm size & 1 & & & & & & & & & \\
\hline 2 & ROA & $0.219^{* *}$ & 1 & & & & & & & & \\
\hline 3 & ROE & $0.099^{* *}$ & $0.137^{* *}$ & 1 & & & & & & & \\
\hline 4 & Market-to-book value & 0.023 & 0.045 & $0.893^{* *}$ & 1 & & & & & & \\
\hline 5 & Indebtedness & $0.062^{*}$ & 0.002 & $0.963^{* *}$ & $0.935^{* *}$ & 1 & & & & & \\
\hline 6 & US listing & -0.001 & 0.007 & 0.010 & 0.023 & 0.000 & 1 & & & & \\
\hline 7 & Industry & $0.127^{* *}$ & $0.138^{* *}$ & 0.035 & -0.036 & 0.000 & $-0 ., 311^{* *}$ & 1 & & & \\
\hline 8 & Political connections & $0.278^{* *}$ & 0.045 & 0.027 & -0.012 & 0.018 & $0.189^{*}$ & $0.211^{* *}$ & 1 & & \\
\hline 9 & $\begin{array}{l}\text { Winning government } \\
\text { contracts }\end{array}$ & $0.270^{* *}$ & $0.128^{* *}$ & $0.107^{* *}$ & $0.083^{* *}$ & $0.080^{* *}$ & 0.051 & $0.230^{* *}$ & $0.095^{* *}$ & 1 & \\
\hline 10 & Value of contracts & $0.107^{* *}$ & 0.025 & 0.017 & 0.018 & 0.009 & 0.031 & $0.113^{* *}$ & 0.055 & $0.259^{* *}$ & 1 \\
\hline
\end{tabular}

** Correlation is significant at $\mathrm{p}=0.01$ (two-tailed).

* Correlation is significant at $\mathrm{p}=0.05$ (two-tailed).

Table 5 shows a positive and very significant correlation between political connections and winning government contracts $\left(0.095^{* *}\right)$. In addition, winning government contracts is very significantly correlated to firm size $\left(0.270^{* *}\right)$, ROA $\left(0.128^{* *}\right)$, ROE $\left(0.107^{* *}\right)$, market-to-book value $\left(0.083^{* *}\right)$, indebtedness $\left(0.080^{* *}\right)$, and 
industry $(0.230 * *)$.

Of the independent and control variables, political connections are positively and very significantly correlated to firm size $\left(0.278^{* *}\right)$ and to industry $\left(0.211^{* *}\right)$. Industry is significantly correlated to firm size $\left(0.127^{* *}\right)$ and ROA $\left(0.138^{* *}\right)$. Firm size is significantly correlated to ROA $\left(0.219^{* *}\right)$, to ROE $\left(0.099^{* *}\right)$, to indebtedness $\left(0.062^{*}\right)$, and to value of contracts $\left(0.107^{* *}\right)$. ROA is also significantly correlated to ROE $\left(0.137^{* *}\right)$, while industry is significantly correlated to value of contracts $\left(0.113^{* *}\right)$. However, these coefficients of correlation are not critical enough to create collinearity problem since they are below $50 \%$.

The most critical correlations are between ROE and market-to-book value $\left(0.893^{* *}\right)$, ROE and indebtedness $\left(0.963^{* *}\right)$, and indebtedness and market-to-book value $\left(0.935^{* *}\right)$.

\section{Results of 2SLS Analyses}

To deal with collinearity and potential endogeneity problems, we decided to use a two-stage least-squares model of analysis. Two set of analyses were performed: one with the dummy variable, winning government contracts, and the other with the value of contracts as dependent variable.

\subsection{Results of 2SLS Analyses with Winning Government Contracts as Dependent Variable}

Results of 2SLS analyses in Table 6 show that political connections are positively and significantly associated with winning government contracts ( $p$ value $=0.034$ ), confirming Hypothesis 1 . A similar result is obtained for firm size $(\mathrm{p}$ value $=0.001)$ and $\mathrm{ROE}(\mathrm{p}$ value $=0.000)$. Indebtedness $(\mathrm{p}$ value $=0.005)$ and ROA $(\mathrm{p}$ value $=$ 0.003 ) are negatively and very significantly associated with winning government contracts, whereas no significant association is noted in terms of US financial market listing ( $\mathrm{p}$ value $=0.945)$, industry ( $\mathrm{p}$ value $=$ 0.848 ), or market-to-book value ( $\mathrm{p}$ value $=0.229$ ). The model is very significant (model $\mathrm{p}$ value $=0.000$ ), with an adjusted $\mathrm{R} 2$ of $27 \%$.

Table 6. Results of 2SLS Dependent variable: Winning government contracts

\begin{tabular}{|c|c|c|c|c|c|}
\hline & \multicolumn{2}{|c|}{ Non-standardized coefficients } & \multirow{2}{*}{ Beta } & \multirow{2}{*}{$\mathrm{t}$} & \multirow{2}{*}{$P$ value } \\
\hline & $\mathrm{B}$ & Standard error & & & \\
\hline (Constant) & -0.175 & 0.146 & & -1.197 & 0.233 \\
\hline Political connections & 0.094 & 0.044 & 0.172 & 2.138 & 0.034 \\
\hline US listing & -0.008 & 0.121 & -0.005 & -0.070 & 0.945 \\
\hline Industry & -0.001 & 0.006 & -0.016 & -0.192 & 0.848 \\
\hline Indebtedness & -0.055 & 0.019 & -2.769 & -2.832 & 0.005 \\
\hline Firm size & 0.037 & 0.010 & 0.242 & 3.522 & 0.001 \\
\hline ROA & -1.152 & 0.376 & -0.346 & -3.066 & 0.003 \\
\hline ROE & 0.681 & 0.161 & 3.626 & 4.239 & 0.000 \\
\hline Market-to-book value & -0.014 & 0.012 & -0.598 & -1.207 & 0.229 \\
\hline $\mathrm{R} 2$ & 0.305 & & & & \\
\hline Adjusted R2 & 0.271 & & & & \\
\hline $\mathrm{F}$ & 8.985 & & & & \\
\hline Equation $\mathrm{P}$ value & 0.000 & & & & \\
\hline
\end{tabular}

\subsection{Results of 2SLS Analyses with Value of Contracts as Dependent Variable}

Table 7 shows that political connections do not significantly influence the value of contracts awarded to companies $(\mathrm{p}$ value $=0.189)$. Of the control variables, firm size $(\mathrm{p}$ value $=0.038)$ and $\mathrm{ROE}(\mathrm{p}$ value $=0.000)$ positively and significantly influence the value of contracts awarded, while this influence is negative for ROA ( $\mathrm{p}$ value $=0.000)$. Market-to-book value $(\mathrm{p}$ value $=0.791)$, US listing $(\mathrm{p}$ value $=0.354)$ and industry $(\mathrm{p}$ value $=$ 0.393 ) have no significant influence on the value of contracts. The model is very significant (model $\mathrm{p}$ value $=$ 0.000), with an adjusted R2 of $33.6 \%$. 
Table 7. Results of 2SLS dependent variable: Value of contracts

\begin{tabular}{|c|c|c|c|c|c|}
\hline & \multicolumn{2}{|c|}{ Non-standardized coefficients } & \multirow{2}{*}{ Beta } & \multirow{2}{*}{$\mathrm{t}$} & \multirow{2}{*}{$\mathrm{P}$ value } \\
\hline & $\mathrm{B}$ & Standard error & & & \\
\hline (Constant) & 383368.071 & 1148086.365 & & 0.334 & 0.739 \\
\hline Political connections & 458052.635 & 347364.327 & 0.101 & 1.319 & 0.189 \\
\hline Firm size & 172133.211 & 82493.628 & 0.137 & 2.087 & 0.038 \\
\hline ROA & -19034227.466 & 2957285.257 & -0.693 & -6.436 & 0.000 \\
\hline ROE & 9844064.247 & 1264507.832 & 6.354 & 7.785 & 0.000 \\
\hline Market-To-Book value & 24801.880 & 93590.473 & 0.125 & 0.265 & 0.791 \\
\hline Indebtedness & -1010821.688 & 151715.754 & -6.217 & -6.663 & 0.000 \\
\hline US listing & -887569.647 & 954417.607 & -0.066 & -0.930 & 0.354 \\
\hline Industry & -43501.951 & 50802.627 & -0.067 & -0.856 & 0.393 \\
\hline $\mathrm{R} 2$ & 0.367 & & & & \\
\hline Adjusted R2 & 0.336 & & & & \\
\hline $\mathrm{F}$ & 11.885 & & & & \\
\hline Equation $\mathrm{P}$ value & 0.000 & & & & \\
\hline
\end{tabular}

\section{Conclusion and Discussion}

Overall, our statistical results confirm our hypotheses respecting winning government contracts. Hypothesis 1 proposed a positive relationship between political connections and winning government contracts among Canadian firms. Political connections positively and significantly influence the receipt of government contracts.

According to Hypothesis 1a, politically connected firms win more government contracts than non-politically connected firms. Hypothesis $1 \mathrm{~b}$ posited that politically connected firms win higher value government contracts than non-politically connected firms. A significant difference was noted between politically connected and non-connected firms in terms of winning government contracts and contract values. In addition, firms with political connections were awarded higher value contracts. However, the two-stage least-squares analyses show that political connections do not significantly influence the value of contracts awarded. In this respect, political connections have more influence on the securing of government contracts than on the value of contracts.

Our study is the first to demonstrate a direct relationship between firms' political connections and government contracts in the Canadian context. The results confirm the trend towards a strong interdependence between politics and business, particularly the increase in corporate actions intended to influence government decisions. These results confirm the theories put forward by numerous authors (Bierman, 1999; Hillman \& Hitt, 1999; Hillman, Zardkhoohi, \& Bierman, 1999; Lord, 2000; Shaffer \& Hillman, 2000; Wawro, 2001; Schuler, Schnietz, \& Baggett, 2002; Hillman, 2003; 2005) who argue that firms' political actions serve as a means to bring them to closer to politics and government institutions and to exercise control. These authors also maintain that such political actions could be part of non-market strategies that enable firms to access resources they need.

The results of this study also provide empirical support to social theories that view companies (and their activities) as part of a greater social structure. Within this social structure, companies and government interact through their social relationships. Our results show that these social relationships are totally integrated in economic transactions. As noted in the results section, $48 \%$ of S\&P/TSX firms are politically connected. But this is only one type of connection. Dicko (2011) has shown that companies have three types of connections: economic (relationships between companies), political (relationships between companies, politics and government organisations), and social (relationships between companies and other organisations such as not-for-profit organisations, associations, clubs, and professional affiliations). Extensive literature on board interlocking has also shown that firms' board interlocks (i.e. economic connections) are widespread (Burris, 2005). Finally, it should be noted that all these companies' connections are often among the same elite groups (Burris, 2005).

From an ethical point of view, it is important for society to be aware of how the government spends public funds and to understand the motivations behind its investment decisions. These results are also supported by social capital and resource dependence theories: firms can use social connections to access external resources by influencing government policies. Our results support Agrawal and Knoeber (2001) in their study of the US context and confirm that political connections can help firms gain access to multiple resources, such as commercial contracts. 


\section{Practical Implications}

The study findings have implications on at least three levels: managerial, regulatory and governmental organisations. Firms can consider political connections to be a non-market, long-term strategy to help them gain competitive advantages and improve performance (Hadani, 2007). They can strategically appoint directors and managers according to the advantages their political connections can bring (Maman, 2000). However, they must carefully consider the cost-benefit ratio of this strategy. Although political connections can have a positive impact, they could also involve negative costs. These costs could be ethical in that firms could find themselves in a position of conflict of interest that would spark extensive media exposure. For example, in Quebec, the Charbonneau Commission revealed numerous instances of corruption and collusion in the process for awarding contracts in the construction industry due to the relationships between some construction firms and politicians.

These results alert regulatory and governmental organisations to the need for them to remain vigilant and strengthen corporate governance regulations to prevent the excesses and abuses that could arise from firms' political actions.

\section{References}

Agrawal, A., \& Knoeber, C. R. (2001). Do Some Outside Directors Play a Political Role? Journal of Law and Economics, 44(1), 179-198. http://dx.doi.org/10.2307/2331397

Boubakri, N., Mansi, S. A., \& Saffar, W. (2013). Political Institutions, Connectedness, and Corporate Risk-Taking. Journal of International Business Studies, 44, 195-215. http://dx.doi.org/10.1057/jibs.2013.2

Bourdieu, P. (1980). Le capital social: Notes provisoires. Actes de la Recherche en Sciences Sociales, 31, 2-3.

Bourdieu, P. (1986). The Forms of Capital. In J. G. Richardson (Ed.), Handbook of Theory and Research for the Sociology of Education ( pp. 241-258).

Bourdieu, P. (2000). Les structures sociales de l'économie. Paris: Éditions du Seuil.

Breton, G., \& Pesqueux, Y. (2006). Business in society or an integrated vision of governance. Society and Business Review, 1(1), 7-27. http://dx.doi.org/10.1108/17465680610643319

Brockman, P., Rui, O. M., \& Zou, H. (2013). Institutions and the performance of politically connected M\&As. Journal of International Business Studies, 44, 833-852. http://dx.doi.org/10.1057/jibs.2013.37

Burris, V. (2005). Interlocking Directorates and Political Cohesion among Corporate Elites. American Journal of Sociology, 111(1), 249-283. http://www.jstor.org/stable/10.1086/428817

Charumilind, C., Kali, R., \& Wiwattanakantang, Y. (2006). Connected Lending: Thailand before the Financial Crisis. Journal of Business, 79(1), 181-217. http://www.jstor.org/stable/10.1086/497410

Chen, Y. S., Shen, C. H., \& Lin, C. Y. (2014). The Benefits of Political Connection: Evidence from Individual Bank-Loan Contracts. J. Financ. Serv. Res., 45, 287-305. http://dx.doi.org/10.1007/s10693-013-0167-1

Claessens, S., Feijen, E., \& Laeven, L. (2008). Political Connections and Preferential Access to Finance: The Role of Campaign Contributions. Journal of Financial Economics, 88(3), 554-580. http://dx.doi.org/10.1016/j.jfineco.2006.11.003

Dicko, S. (2011). Réseaux de relations sociales des membres du conseil d'administration et acquisition de ressources: Le cas de Power Corporation du Canada. Montreal: PhD Thesis, Université du Québec à Montréal.

Dicko, S., \& Khemakhem, H. (2015). S\&P/TSX 300 Companies' Political Connections, Compliance with Board of Directors Regulations and Financial Performance. International Journal of Business and Management, 10(1), 14-24. http://dx.doi.org/doi:10.5539/ijbm.v10n1p14

Dinc, I. S. (2005). Politicians and banks: Political influences on government-owned banks in emerging markets. Journal of Financial Economics, 77, 453-479. http://dx.doi.org/10.1016/j.jfineco.2004.06.011

Faccio, M. (2006). Politically Connected Firms. The American Economic Review, 96(1), 369-386. http://dx.doi.org/10.1257/000282806776157704

Faccio, M., Masulis, R. W., \& McConnell, J. J. (2006). Political Connections and Corporate Bailouts. The Journal of Finance, LXI(6), 2597-2635. http://dx.doi.org/10.1111/j.1540-6261.2006.01000.x

Galaskiewicz, J. (1985). Interorganizational Relations. Annual Review of Sociology, 11281-11304. http://dx.doi.org/10.1146/annurev.so.11.080185.001433 
Getz, K. A. (1997). Research in Corporate Political Action: Integration and Assessment. Business \& Society, 36, 32-72. http://dx.doi.org/10.1177/000765039703600103

Goldman, E., Rocholl, J., \& So, J. (2009). Do Politically Connected Boards Affect Firm Value? The Review of Financial Studies, 22(6), 2331-2360. http://dx.doi.org/10.1093/rfs/hhn088

Goldman, E., Rocholl, J., \& So, J. (2013). Politically Connected Boards of Directors and the Allocation of Procurement Contracts. Review of Finance, 17, 1617-1648. http://dx.doi.org/10.1093/rof/rfs039

Hadani, M. (2007). Family Matters: Founding Family Firms and Corporate Political Activity. Business \& Society, 46(4), 395-428. http://dx.doi.org/10.1177/0007650306293394

Hill, S. (1995). The Social Organization of Boards of Directors. The British Journal of Sociology, 46(2), 245-278. http://dx.doi.org/10.2307/591788

Hillman, A. J. (2003). Determinants of Political Strategies in US Multinationals. Business \& Society, 42, 455-484. http://dx.doi.org/10.1177/0007650303260351

Hillman, A. J. (2005). Politicians on the Board of Directors: Do Connections Affect the Bottom Line? Journal of Management, 31(3), 464-481. http://dx.doi.org/10.1177/0149206304272187

Hillman, A. J., \& Hitt, M. A. (1999). Corporate Political Strategy Formulation: A Model of Approach, Participation and Strategy Decisions. Academy of Management Review, 24, 825-842.

Hillman, A. J., Zardkhoohi, A., \& Bierman, L. (1999). Corporate political strategies and firm performance: Indications of firm-specific benefits from personal service in the U.S. government. Strategic Management Journal, 20, 67-81. http://dx.doi.org/10.1002/(SICI)1097-0266(199901)20:1<67::AID-SMJ22>3.0.CO;2-T

Houston, J., Jiang, L. L., Lin, C., \& Yuema. (2014). Political Connections and the Cost of Bank Loans. Journal of Accounting Research, 52(1), 193-243. http://dx.doi.org/10.1111/1475-679X.12038

Kersh, R. (2002). State Autonomy \& Civil Service: The Lobbyist Connection. Critical Review, 14, 237-258. http://dx.doi.org/10.1080/08913810008443559

Khemakhem, H., \& Dicko, S. (2013). Directors' Political Connections and Compliance with Board of Directors Regulations: The Case of S\&P/TSX 300 Companies. International Journal of Business and Management, 8(24), 117-125. http://dx.doi.org/10.5539/ijbm.v8n24p117

Lemieux, V. (2000). À quoi servent les réseaux sociaux? Québec: Les Éditions de l'IQRC (Institut Québécois de Recherche sur la Culture).

Lord, M. (2000). Corporate political strategy and legislative decision making: The impact of corporate legislative influence activities, Business \& Society, 39, 76-93. http://dx.doi.org/10.1177/000765030003900106

Maman, D. (2000). Who Accumulates Directorships of Big Business Firms in Israel? Organizational Structure, Social Capital and Human Capital. Human Relations, 53(5), 603-629. http://dx.doi.org/10.1177/0018726700535001

Mizruchi, M. S. (1996). What Do Interlocks Do? An Analysis, Critique, and Assessment of Research on Interlocking Directorates. Annual Review of Sociology, 22, 271-298. http://dx.doi.org/10.1146/annurev.soc.22.1.271

Pfeffer, J. (1981). Power in Organizations. Marshfield, Mass. Pitman.

Pfeffer, J., \& Salancik, G. R. (1978). The External Control of Organizations: A Resource Dependence Perspective. New York: Harper \& Row.

Schuler, D. A., Schnietz, K. A., \& Baggett, L. S. (2002). Determinants of foreign trade mission participation, Business \& Society, 41, 6-36. http://dx.doi.org/10.1177/0007650302041001003

Shaffer, B., \& Hillman, A. J. (2000). The development of business-government strategies by diversified firms. $\begin{array}{llll}\text { Strategic Management } & \text { Journal, } & \text { 175-190. }\end{array}$ http://dx.doi.org/10.1002/(SICI)1097-0266(200002)21:2<175::AID-SMJ86>3.0.CO;2-L

Wang, C. (2014). Political Connections of the Boards of Directors and Department of Defense Contractors' Excessive Profits. Journal of Public Procurement, 14(1), 96-122.

Wawro, G. (2001). A panel probit analysis of campaign contributions and roll-call votes. American Journal of Political Science, 45, 563-579. http://dx.doi.org/10.2307/2669239

Yang, F., Wilson, C., \& Wu, Z. (2014). Investor Perceptions of the Benefits of Political Connections: Evidence 
from China's A-share Premiums. International Journal of Managerial Finance, 10(3), $312-331$. http://dx.doi.org/10.1108/IJMF-08-2012-0093

Zald, M. N. (1969). The Power and Functions of Boards of Directors: A Theoretical Synthesis. The American Journal of Sociology, 75(1), 97-111. http://dx.doi.org/10.1086/224747

\section{Note}

Note 1. See the Commission website at https://www.ceic.gouv.qc.ca/la-commission.html

\section{Copyrights}

Copyright for this article is retained by the author(s), with first publication rights granted to the journal.

This is an open-access article distributed under the terms and conditions of the Creative Commons Attribution license (http://creativecommons.org/licenses/by/3.0/). 